\title{
Assessment of Acute Antipsychotic Poisoned Cases Admitted to Tanta University Poison Control Unit
}

\author{
Marwa A. Mubarak, Enas I. El Madah, Doaa M. El Gharbawy and Magdy M. Ashmawy ${ }^{1}$ \\ Department of Forensic Medicine and Clinical Toxicology, Faculty of Medicine, Tanta University, Tanta, Egypt.
}

\begin{abstract}
Background: Sedative hypnotic/antipsychotic poisoning represented 5.84\% of cases according to national poison data system in 2017. In Egypt, studies about antipsychotic poisoning are scarce.

Objectives: is to assess the pattern of toxicity and prognosis of cases with acute antipsychotic poisoning admitted to Tanta University Poison Control Unit.

Patients and Methods: This study was conducted on cases who admitted to Tanta University Poison Control Unit with acute antipsychotics poisoning. All cases were subjected to clinical evaluation, laboratory investigations and electrocardiogram. Severity was assessed by poison severity score.

Results: Majority of cases were represented equally in age groups (0-10) and (11-20) years with $33.3 \%$ for each age group, $65 \%$ of cases were females, most of cases were from urban areas $(71.7 \%)$ and singles (71.7\%). History of mental disorder found in $31.6 \%$ of cases and suicidal attempts represented the most common manner of poisoning (71.7\%). Clozapine was the highest antipsychotic drug taken $(35 \%)$ and $6.7 \%$ of cases developed extrapyramidal manifestations. Miosis was found in $56.7 \%$ of cases. Tachycardia was recorded in $46.7 \%$ of cases and QTc interval was prolonged in $43 \%$ of cases. According to poison severity score, most studied cases were either mild $(51.7 \%)$ or moderate $(33.7 \%)$. One case was admitted to ICU. Multiple regression analysis showed that decreased GCS, $\mathrm{PCO}_{2}, \mathrm{O}_{2}$ saturation were associated with increased hospital stay.

Conclusion: Antipsychotic poisoning was commonly mild to moderate. Neurological and cardiovascular manifestations were the predominant. Sinus tachycardia and prolonged QTc were the most common electrocardiographic changes. Antipsychotic poisoning usually had a good prognosis.
\end{abstract}

Key words antipsychotics, accidental poisoning, suicidal poisoning

\section{Introduction}

$\mathrm{D}$

rug overdose is the most common cause of acute poisoning worldwide. Moreover, poisoning is the most frequent method of suicide attempts in which psychotropic drugs as antipsychotics, antidepressants and benzodiazepines are significantly used (Kim et al., 2015, Mowry et al., 2016).

Antipsychotics are primary used to treat schizophrenia, manic phase of bipolar disorders and agitated behavior; however they are often used to treat nausea, vomiting, headache, and various neurological conditions (chorea, dystonia and tics). Antipsychotics toxic effects include anticholinergic and extrapyramidal syndromes as well as CNS and cardiovascular depression (Georgiev et al., 2015).

Antipsychotics are classified into two groups: typical and atypical. The typical one or the first generation includes the older drugs as butyrophenones, dibenzoxazepines, diphenylbutylpiperidine and phenothiazines. Atypical group or the second generation includes the newer drugs as benzopines, indoles, quinolinone (DeSilva et al., 2006).

Diagnosis of antipsychotic overdose is based on history coupled with predictable symptoms and physical findings. Plasma concentrations of antipsychotics are not widely available and not useful in management of acute antipsychotic overdose, this demonstrates the importance of clinical evaluation in diagnosing these cases (Minns and Clark, 2012).

Supportive care is the cornerstone for treatment of antipsychotic overdose. Gastrointestinal decontamination with activated charcoal should be done. No specific antidote is present. Cardiovascular complications are managed by intravenous fluids, vasopressors if needed and sodium bicarbonate in cases of ventricular dysrhythmia. Seizures are treated with benzodiazepines followed by phenobarbital. Hemoperfusion and hemodialysis are not effective (Isbister et al., 2007, Minns and Clark, 2012). 


\section{Aim of the work}

This study aimed to assess the pattern of toxicity in acute antipsychotic poisoned cases admitted to Tanta University Poison control Unit at emergency hospital.

\section{Patients and Methods}

This study was conducted on cases admitted to Tanta University Poison Control Unit with history, symptoms and signs of acute antipsychotics poisoning. Cases were selected by convenience sampling (this means that all cases with antipsychotic poisoning admitted at this period were included in this study without randomization) in the period from the $1^{\text {st }}$ of November 2016 to $1^{\text {st }}$ of November 2017. The study was carried out after approval of the medical research ethical committee of Tanta Faculty of Medicine. Written informed consent was signed by the cases or their guardians after explaining the aim and method of the study. The exclusion criteria included patients who refused to sign the informed consent and patients with chronic poisoning, co-ingestion, chronic illness or patients with history of drug addiction.

\section{Methods}

All cases were subjected to sociodemographic evaluation including age, sex, occupation, educational level, residence, marital status and special habits; smoking, coffee and alcohol. Additionally, past medical history, history of previous admission to hospital, toxicological history including name of drug, its form, route of intake, amount of drug taken, manner of poisoning, reason in case of intentional poisoning, time of drug intake, time of hospital admission and delay time were recorded. Clinical examination was conducted through physical examination; vital signs, level of consciousness using Glasgow coma scale and systemic examination. Severity of cases was assessed by poison severity score (Persson et al., 1998). Laboratory investigations were measured including arterial blood gases, liver enzymes, kidney function tests, complete blood count, electrolytes (sodium, potassium and magnesium) and random blood sugar. Electrocardiogram was done for the studied patients. Medical treatment was done according to protocol of antipsychotic treatment in Tanta poison control unit.

Outcome measures (prognosis) were recorded including duration of hospital stay, complete recovery, complications, need for intubation, ventilation, intensive care unit or death.

\section{Statistical analysis}

Was conducted by IBM SPSS software package version 21 including descriptive statistics (number, percentage, minimum, maximum, mean, standard deviation). Chisquare, Kruskal-Wallis, median, $\mathrm{t}$ test and one-way ANOVA were done also to identify factors influencing manner of poisoning, effect of antipsychotic poisoning on clinical and biochemical parameters of cases and regression analysis to test factors affecting outcome.

\section{Results}

Socio-demographic study showed that most of cases were in age groups (0-10) and (11-20) years with 33.3\% for each age group followed by age group (21-30) years representing $30 \%$ of cases. More than half of the studied cases were females $(65 \%)$. Most of cases were unemployed $(35 \%)$, while, $33.3 \%$ were students, and $50 \%$ were secondary educated. The majority of cases were from urban areas and singles (71.7\%). Only $11.7 \%$ were smokers. (Table 1)

Toxicological findings demonstrated that $66.7 \%$ had no past medical history, while $31.6 \%$ were mentally ill. Manner of poisoning in $71.7 \%$ of cases was suicidal followed by accidental (28.3\%). Intentional poisoning was due to family troubles $(40 \%)$ followed by psychiatric illness $(28.3 \%)$. Clozapine was the drug used in $35 \%$ of cases, followed by risperidone (20\%), chlorpromazine (15\%), quetiapine (11.7\%), olanzapine (6.7\%), haloperidol (3.3\%), and aripiprazole (3.3\%). All cases were poisoned orally by tablets $(91.7 \%)$ followed by syrup $(8.3 \%)$. Most of cases were admitted within 5 hours from drug ingestion (75\%) (Table 2).

Analysis of the above data showed highly significant association between manner of poisoning and age groups ( $\mathrm{p}$ value $<0.001$ ). All cases of accidental poisoning were less than 10 years while most of cases with suicidal poisoning were focused in two age groups (>10-20 and >20-30 years). Additionally, there was a significant association between manner of poisoning and educational level as most of cases with accidental poisoning were in preschool and kindergarten children while most cases with suicidal poisoning were encountered among patients of secondary school and post graduates $(p=0.001)$. Also, a significant association was found between manner of poisoning and residence ( $p$ value $=0.002$ ) where both accidental and suicidal poisoning were more common in urban than rural areas. Regarding history of medical disease; most of cases with accidental poisoning had no past medical history $(82.35 \%)$ while no history of medical diseases was found in $60.5 \%$ in cases of suicidal poisoning. This difference is statistically significant $(\mathrm{p}=0.026)$ (Table 5).

There was a statistical significant difference between cases with suicidal and accidental poisoning regarding past medical history as most of cases with accidental poisoning had no history of medical diseases $(82.35 \%)$ and $11.76 \%$ of them suffered from mental disorders. while, in cases with suicidal poisoning $60.5 \%$ had no history of medical diseases and $39.5 \%$ / gave a history of mental diseases (Table 5).

The present study demonstrated that $51.7 \%$ of cases were classified as mild poisoning according to PSS while $33.3 \%$ were moderate and only $5 \%$ showed severe toxicity on admission. Clinical evaluation of the studied cases showed that $5 \%$ of cases suffered from mild GIT manifestations, $3.3 \%$ were presented with moderate respiratory manifestations. Regarding CNS manifestations, $43.3 \%$ suffered from mild manifestations 
and $18.3 \%$ were moderate. About half of the studied cases $(55 \%)$ showed no cardiovascular manifestations while, $43.3 \%$ had mild and $1.7 \%$ had moderate cardiovascular findings. ECG findings in the present study revealed sinus tachycardia in $50 \%$ of cases and the other half had normal heart rate, all cases showed regular rhythm, normal QRS complex. QTc interval was prolonged in $43 \%$ of cases, $t$ wave was flat in $5 \%$ of cases and inverted in 5\% of cases. The other clinical and laboratory findings are summarized in tables $(3,4)$.

Mean duration of hospital stay was $15.45 \pm$ 12.37 hours. Most of cases $(90 \%)$ stayed for 24 hours and $10 \%$ stayed more than 24 hours.

Regarding outcome of the studied cases this study showed that $53.3 \%$ of cases were discharged after complete recovery, $43.3 \%$ were discharged on patient request and $3.3 \%$ (two cases) were discharged with pneumonia and needed chest care; one of them was admitted to intensive care unit (ICU). No cases needed endotracheal intubation, mechanical ventilation, or developed neuroleptic malignant syndrome and no cases died. Statistical significance was detected between hospital stay duration and manner of poisoning where accidental poisoning stayed in the hospital longer than suicidal poisoning (table 6). Also, there was a significant difference between hospital stay duration and GCS as cases with low GCS $(<12)$ stayed in the hospital for longer duration than cases with high or normal GCS. Additionally, there was a significant difference between hospital stay duration and pupil size as cases with constricted pupil (36.7\%) stayed in the hospital for longer duration than cases with normal pupil size. Results demonstrated significance between PSS-CNS severity and hospital stay duration (table 7).

Table 8 demonstrated the results of multiple regression analysis of hospital stay duration as dependent variable and both clinical, and laboratory findings as independent ones which showed that decreased GCS, $\mathrm{PCO}_{2}$, and $\mathrm{O}_{2}$ saturation could predict long hospital stay duration.

Table (1): Socio-demographic data of the studied patients (60 cases) with acute antipsychotic poisoning:

\begin{tabular}{|l|c|c|c|}
\hline Variable & & $\mathbf{N}$ & $\mathbf{\%}$ \\
\hline Age group & $0-10$ years & 20 & 33.33 \\
& $>10-20$ years & 20 & 33.33 \\
& $>20-30$ years & 18 & 30 \\
& $>30$ years & 2 & 3.34 \\
\hline Gender & Female & 39 & 65.0 \\
\cline { 2 - 4 } & Male & 21 & 35.0 \\
\hline Occupation & Unemployed & 21 & 35.0 \\
\cline { 2 - 4 } & Student & 20 & 33.3 \\
\cline { 2 - 4 } & House wife & 9 & 15.0 \\
\cline { 2 - 4 } & Skilled worker & 7 & 11.7 \\
\cline { 2 - 4 } & Professional & 3 & 5.0 \\
\hline Education & Secondary & 30 & 50.0 \\
\cline { 2 - 4 } & Preschool & 11 & 18.3 \\
\cline { 2 - 4 } & Post graduate & 7 & 11.7 \\
\cline { 2 - 4 } & Primary & 5 & 8.3 \\
\cline { 2 - 4 } & Kindergarten & 4 & 6.7 \\
\cline { 2 - 4 } & University & 2 & 3.3 \\
\cline { 2 - 4 } & Preparatory & 1 & 1.7 \\
\hline Residence & Urban & 43 & 71.7 \\
\cline { 2 - 4 } & Rural & 17 & 28.3 \\
\hline Marital status & Single & 43 & 71.7 \\
\cline { 2 - 4 } & Married & 17 & 28.3 \\
\hline Special Habits & No special habits & 53 & 88.3 \\
\cline { 2 - 4 } & Smoker & 7 & 11.7 \\
\hline
\end{tabular}

$N:$ number 
Table (2): Medical and toxicological findings of the studied cases (60 cases) with acute antipsychotic poisoning:

\begin{tabular}{|l|l|c|c|}
\hline Medical and Toxicological history & & $\mathbf{N}$ & $\mathbf{\%}$ \\
\hline \multirow{4}{*}{ Past medical history } & No history of special medical disease & 40 & 66.7 \\
\cline { 2 - 4 } & History of mental disorders & 19 & 31.6 \\
\cline { 2 - 4 } & History of bronchial asthma & 1 & 1.7 \\
\hline \multirow{5}{*}{ Reasons of intentional poisoning } & Suicidal & 43 & 71.7 \\
\cline { 2 - 4 } & Accidental & 17 & 28.3 \\
\hline \multirow{5}{*}{ Drugs taken } & Family troubles & 24 & 40.0 \\
\cline { 2 - 4 } & Psychiatric illness & 17 & 28.4 \\
\cline { 2 - 4 } & Learning problems & 2 & 3.3 \\
\hline & Clozapine & 21 & 35.0 \\
\cline { 2 - 4 } & Risperidone & 12 & 20.0 \\
\cline { 2 - 4 } & Chlorpromazine & 9 & 15.0 \\
\cline { 2 - 4 } & Quetiapine & 7 & 11.7 \\
\cline { 2 - 4 } & Olanzapine & 4 & 6.6 \\
\cline { 2 - 4 } & Aripiprazole & 2 & 3.3 \\
\cline { 2 - 4 } & Haloperidol & 2 & 3.3 \\
\cline { 2 - 4 } & Amisulpride & 1 & 1.7 \\
\cline { 2 - 4 } & Combined (Risperidone and Quetiapine) & 1 & 1.7 \\
\cline { 2 - 4 } & Combined (Chlorpromazine and Risperidone) & 1 & 1.7 \\
\hline Route of intake & Oral & 60 & 100 \\
\hline Form of the drug taken & Tablet & 55 & 91.7 \\
\cline { 2 - 4 } & Syrup & 5 & 8.3 \\
\hline Delay time & $1-5$ hours & 45 & 75 \\
\cline { 2 - 4 } & $>5-10$ hours & 9 & 15 \\
\cline { 2 - 4 } & $>10-15$ hours & 5 & 8.3 \\
\cline { 2 - 4 } & $>15-20$ hours & 1 & 0 \\
\cline { 2 - 4 } & $>20$ hours & 1.7 \\
\hline
\end{tabular}

$N$ : number. 
Table (3): Clinical evaluation of the studied cases (60 cases) with acute antipsychotic poisoning:

\begin{tabular}{|c|c|c|c|}
\hline & & $\mathbf{N}$ & $\%$ \\
\hline \multirow[t]{3}{*}{ Pulse rate (beats/min) } & Normal & 32 & 53.33 \\
\hline & Tachycardia & 28 & 46.67 \\
\hline & Bradycardia & 0 & 0.00 \\
\hline \multirow[t]{3}{*}{ Blood pressure $(\mathrm{mmHg})$} & Normotensive & 54 & 90.00 \\
\hline & Hypotensive & 3 & 5.00 \\
\hline & Hypertensive & 3 & 5.00 \\
\hline \multirow{3}{*}{ Respiratory rate (Cycles/min) } & Normal & 32 & 53.33 \\
\hline & Tachypnea & 28 & 46.67 \\
\hline & Bradypnea & 0 & 0.00 \\
\hline \multirow[t]{3}{*}{ Temperature $\left({ }^{\circ} \mathrm{c}\right)$ (axillary) } & Normal & 57 & 95.00 \\
\hline & Hyperthermia & 3 & 5.00 \\
\hline & Hypothermia & 0 & 0.00 \\
\hline \multirow[t]{3}{*}{ GCS score } & $3-8$ & 5 & 8.3 \\
\hline & $9-12$ & 4 & 6.7 \\
\hline & $13-15$ & 51 & 85.00 \\
\hline \multirow[t]{3}{*}{ Speech } & Normal & 35 & 58.3 \\
\hline & Slurred comprehensible & 22 & 36.7 \\
\hline & Slurred un comprehensible & 3 & 5.0 \\
\hline \multirow[t]{2}{*}{ Head and neck } & Free & 56 & 93.3 \\
\hline & Dystonia or dyskinesia & 4 & 6.7 \\
\hline \multirow[t]{3}{*}{ Pupil } & Constricted & 34 & 56.7 \\
\hline & Normal & 24 & 40.0 \\
\hline & Dilated & 2 & 3.3 \\
\hline \multirow[t]{4}{*}{ Chest } & Free & 56 & 93.3 \\
\hline & Crepitation & 2 & 3.3 \\
\hline & Diminished air entry & 1 & 1.7 \\
\hline & Wheezing & 1 & 1.7 \\
\hline Abdomen & Free & 60 & 100.0 \\
\hline \multirow[t]{2}{*}{ Extremities } & Free & 59 & 98.3 \\
\hline & Involuntary movements & 1 & 1.7 \\
\hline \multirow[t]{4}{*}{ Poison Severity Score } & None & 6 & $10.0 \%$ \\
\hline & Mild & 31 & $51.7 \%$ \\
\hline & Moderate & 20 & $33.3 \%$ \\
\hline & Severe & 3 & $5.0 \%$ \\
\hline
\end{tabular}

N: number, GCS: Glasgow Coma Scale 
Table (4) Laboratory findings of studied cases (60 cases) with acute antipsychotic poisoning.

\begin{tabular}{|c|c|c|c|}
\hline & & $\mathbf{N}$ & $\%$ \\
\hline \multirow[t]{4}{*}{ Arterial Blood gases } & Normal & 40 & 66.7 \\
\hline & Respiratory acidosis & 2 & 3.3 \\
\hline & Respiratory alkalosis & 16 & 26.7 \\
\hline & Mixed disorder & 2 & 3.3 \\
\hline \multirow[t]{3}{*}{ Sodium $(\mathrm{mEq} / \mathrm{L})$} & Normal & 59 & 98.3 \\
\hline & Hypernatremia & 1 & 1.7 \\
\hline & Hyponatremia & 0 & 0 \\
\hline \multirow[t]{3}{*}{ Potassium $(\mathrm{mEq} / \mathrm{L})$} & Normal & 51 & 85 \\
\hline & Hypokalemia & 9 & 15 \\
\hline & Hyperkalemia & 0 & 0 \\
\hline Magnesium (mg/dL) & Normal & 60 & 100 \\
\hline \multirow[t]{3}{*}{ Random blood sugar (mg/dL) } & Normal & 51 & 85 \\
\hline & Hyperglycemia & 9 & 15 \\
\hline & Hypoglycemia & 0 & 0 \\
\hline \multirow{3}{*}{$\begin{array}{l}\text { Liver enzymes } \\
(\mathrm{U} / \mathrm{L})\end{array}$} & Normal & 59 & 98.3 \\
\hline & Increased & 1 & 1.7 \\
\hline & Decreased & 0 & 0 \\
\hline Kidney Function (mg/dl) & Normal & 60 & 100 \\
\hline \multicolumn{4}{|l|}{ Complete Blood Count } \\
\hline \multirow[t]{2}{*}{ Hb (gm/dl) } & Normal & 4 & 6.7 \\
\hline & Abnormal & 56 & 93.3 \\
\hline \multirow[t]{2}{*}{ RBCs (mcL) } & Normal & 47 & 78.3 \\
\hline & Abnormal & 13 & 21.7 \\
\hline \multirow[t]{2}{*}{ WBCs (mcL) } & Normal & 48 & 80 \\
\hline & Abnormal & 12 & 20 \\
\hline \multirow[t]{2}{*}{ Platelets (mcL) } & Normal & 59 & 98.3 \\
\hline & Abnormal & 1 & 1.7 \\
\hline
\end{tabular}

$n=$ Number, $m E q / L=$ milliEquivalents per Liter, $\overline{m g / d L=}$ milligrams per deciliter, U/L=Unit per Liter gm/dl= gram per deciliter, mcL: microliter. 
Table (5): Association between manner of poisoning and sociodemographic data in the studied cases of (60 cases) acute antipsychotic poisoning:

\begin{tabular}{|c|c|c|c|c|c|c|c|}
\hline & \multicolumn{4}{|c|}{ Manner of poisoning } & \multicolumn{2}{|c|}{ Tests of significance } \\
\hline & & \multirow{2}{*}{\multicolumn{2}{|c|}{$\begin{array}{c}\begin{array}{c}\text { Accidental } \\
(\mathbf{N}=\mathbf{1 7})\end{array} \\
4 \pm 2\end{array}$}} & \multirow{2}{*}{\multicolumn{2}{|c|}{$\begin{array}{c}\begin{array}{c}\text { Suicidal } \\
(\mathbf{N}=\mathbf{4 3})\end{array} \\
21+6\end{array}$}} & \multirow{3}{*}{$\begin{array}{c}\text { Test Statistic } \\
-14.961^{\mathrm{a}}\end{array}$} & \multirow{3}{*}{$\begin{array}{c}\mathbf{p} \\
<0.001^{*}\end{array}$} \\
\hline Age (Years) & \pm SD & & & & & & \\
\hline & & $\mathrm{N}$ & $\%$ & $\mathrm{~N}$ & $\%$ & & \\
\hline Age groups & $\begin{aligned} & 0-10 \\
> & 10-20 \\
> & 20-30 \\
> & 30\end{aligned}$ & $\begin{array}{c}17 \\
0 \\
0 \\
0\end{array}$ & $\begin{array}{c}100.0 \% \\
0.0 \% \\
0.0 \% \\
0.0 \%\end{array}$ & $\begin{array}{c}3 \\
20 \\
18 \\
2\end{array}$ & $\begin{array}{c}6.98 \% \\
46.51 \% \\
41.86 \% \\
4.65 \%\end{array}$ & $46.891^{b}$ & $<0.001 *$ \\
\hline Gender & $\begin{array}{l}\text { Female } \\
\text { Male }\end{array}$ & $\begin{array}{l}9 \\
8\end{array}$ & $\begin{array}{l}52.9 \% \\
47.1 \%\end{array}$ & $\begin{array}{l}30 \\
13\end{array}$ & $\begin{array}{l}69.8 \% \\
30.2 \%\end{array}$ & $1.516^{\mathrm{c}}$ & 0.218 \\
\hline Education & $\begin{array}{l}\text { KG1 } \\
\text { Preschool } \\
\text { Post graduate } \\
\text { Preparatory school } \\
\text { Primary school } \\
\text { Secondary School } \\
\text { University }\end{array}$ & $\begin{array}{c}4 \\
11 \\
0 \\
0 \\
2 \\
0 \\
0\end{array}$ & $\begin{array}{c}23.5 \% \\
64.7 \% \\
0.0 \% \\
0.0 \% \\
11.8 \% \\
0.0 \% \\
0.0 \%\end{array}$ & $\begin{array}{c}0 \\
0 \\
7 \\
1 \\
3 \\
30 \\
2\end{array}$ & $\begin{array}{c}0.0 \% \\
0.0 \% \\
16.28 \% \\
2.3 \% \\
6.97 \% \\
69.8 \% \\
4.65 \% \\
\end{array}$ & $4.090^{\mathrm{b}}$ & $0.001 *$ \\
\hline Marital status & $\begin{array}{l}\text { Married } \\
\text { Single }\end{array}$ & $\begin{array}{c}0 \\
17\end{array}$ & $\begin{array}{c}0.0 \% \\
100.0 \%\end{array}$ & $\begin{array}{l}17 \\
26\end{array}$ & $\begin{array}{l}39.5 \% \\
60.5 \%\end{array}$ & $0.270^{\mathrm{b}}$ & 0.604 \\
\hline Residence & $\begin{array}{l}\text { Urban } \\
\text { Rural }\end{array}$ & $\begin{array}{c}13 \\
4\end{array}$ & $\begin{array}{l}76.5 \% \\
23.5 \%\end{array}$ & $\begin{array}{l}30 \\
13\end{array}$ & $\begin{array}{l}69.8 \% \\
30.2 \%\end{array}$ & $9.378^{c}$ & $0.002 *$ \\
\hline Special Habits & $\begin{array}{l}\text { None } \\
\text { Smoker }\end{array}$ & $\begin{array}{c}17 \\
0\end{array}$ & $\begin{array}{c}100.0 \% \\
0.0 \%\end{array}$ & $\begin{array}{c}36 \\
7\end{array}$ & $\begin{array}{l}83.7 \% \\
16.3 \%\end{array}$ & $3.133^{\mathrm{b}}$ & 0.077 \\
\hline Past medical history & $\begin{array}{l}\text { No Past medical history } \\
\text { Mental disorders } \\
\text { Bronchial asthma }\end{array}$ & $\begin{array}{l}14 \\
2 \\
1\end{array}$ & $\begin{array}{l}82.35 \% \\
11.76 \% \\
5.89 \%\end{array}$ & $\begin{array}{c}26 \\
17 \\
0\end{array}$ & $\begin{array}{c}60.5 \% \\
39.5 \% \\
0.0 \%\end{array}$ & $6.135^{\mathrm{b}}$ & $0.026^{*}$ \\
\hline
\end{tabular}

$N$ : number; SD: standard deviation; a: Independent samples $t$ test; $b$ : Fisher-Freeman-Halton Exact Test; *significant at $p<0.05$.

Table (6): Association between hospital stay duration and age groups, gender, past medical history, mode of poisoning and ingested dose in the studied cases ( 60 cases) of acute antipsychotic poisoning.

\begin{tabular}{|c|c|c|c|c|c|c|c|}
\hline & \multicolumn{4}{|c|}{ Hospital Stay (hours) } & \multicolumn{2}{|c|}{ Tests of significance } \\
\hline & & \multicolumn{2}{|c|}{$\begin{array}{c}\leq 13 \\
(N=30)\end{array}$} & \multicolumn{2}{|c|}{$\begin{array}{c}>13 \\
(\mathbf{N}=30)\end{array}$} & Test Statistic & $\mathbf{p}$ \\
\hline \multirow{4}{*}{ Age groups } & $0-10$ & 6 & $20.0 \%$ & 14 & $46.7 \%$ & $5.551^{\mathrm{a}}$ & 0.120 \\
\hline & $>10-20$ & 11 & $36.7 \%$ & 9 & $30.0 \%$ & & \\
\hline & $>20-30$ & 12 & $40.0 \%$ & 6 & $20.0 \%$ & & \\
\hline & $>\mathbf{3 0}$ & 1 & $3.3 \%$ & 1 & $3.3 \%$ & & \\
\hline \multirow{2}{*}{ Gender } & Female & 22 & $73.3 \%$ & 17 & $56.7 \%$ & $1.832^{\mathrm{b}}$ & 0.176 \\
\hline & Male & 8 & $26.7 \%$ & 13 & $43.3 \%$ & & \\
\hline \multirow{3}{*}{ Past medical history } & No history & 20 & $66.7 \%$ & 20 & $66.7 \%$ & $1.015^{\mathrm{a}}$ & 1.000 \\
\hline & Mental disorders & 10 & $33.3 \%$ & 9 & $30.0 \%$ & & \\
\hline & Bronchial asthma & 0 & $0.0 \%$ & 1 & $3.3 \%$ & & \\
\hline \multirow{2}{*}{ Manner of poisoning } & Accidental & 5 & $16.7 \%$ & 12 & $40.0 \%$ & $4.022^{b}$ & $0.045^{*}$ \\
\hline & Suicidal & 25 & $83.3 \%$ & 18 & $60.0 \%$ & & \\
\hline Ingested dose & Median (IQR) & \multirow{2}{*}{\multicolumn{4}{|c|}{\begin{tabular}{l|c}
$500(200-1000)$ & $150(14-900)$ \\
30.1 & 23.8
\end{tabular}}} & $-1.496^{c}$ & 0.135 \\
\hline & Mean ranks & & & & & & \\
\hline
\end{tabular}

N: number; IQR: interquartile range; a: Fisher-Freeman-Halton Exact Test; b: Pearson's Chi test; c: Mann-Whitney test; * significant at $p<0.05$. 
Table (7): Association between hospital stay duration and poison severity score in the studied cases (60 cases) of acute antipsychotic poisoning.

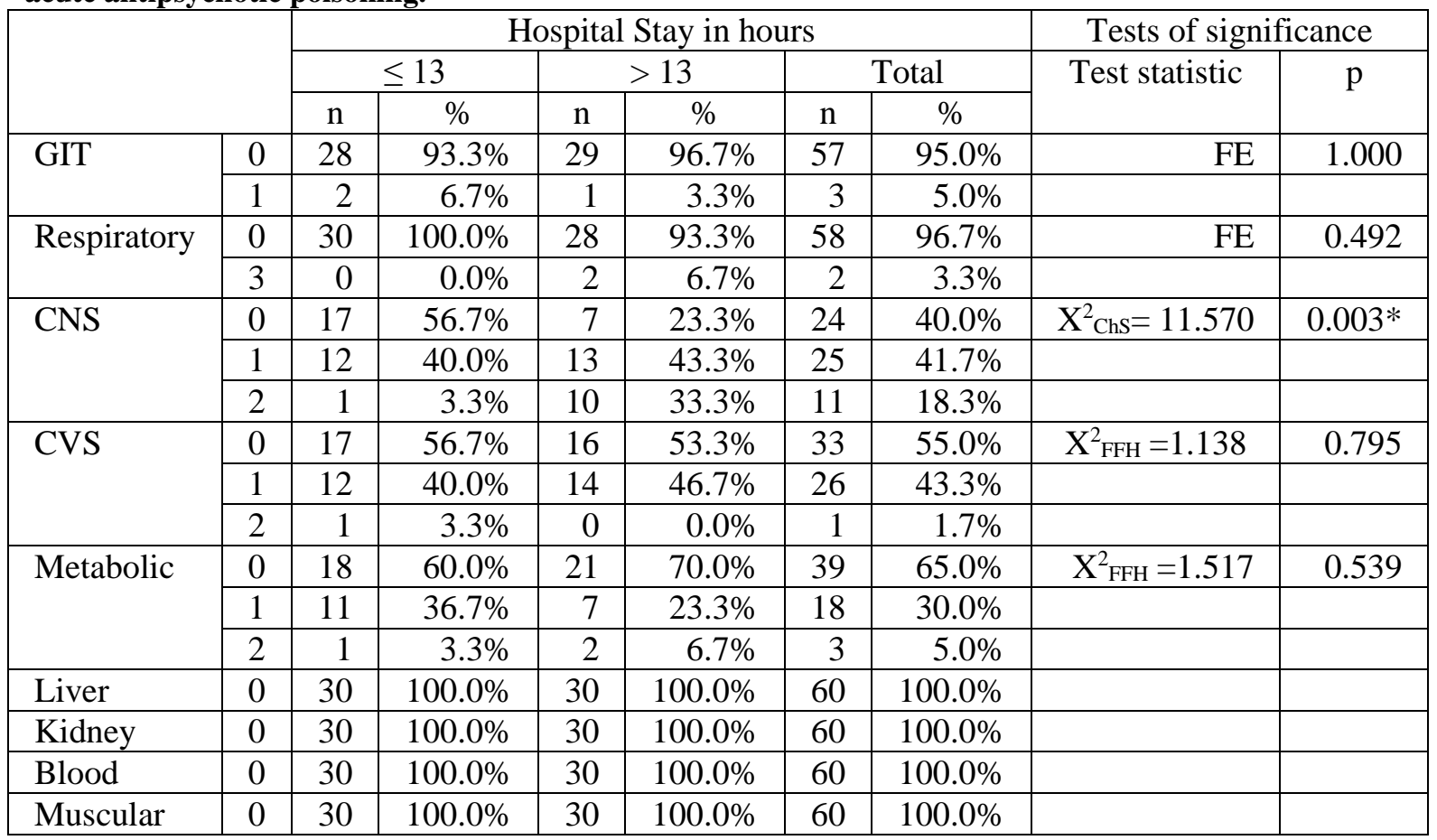

n: number; FE: Fisher's exact test; X2ChS: Pearson's Chi square test; X2FFH: Fisher-Freeman-Halton test; * significant at $p<0.05$.

Table (8): Multiple regression analysis test

\begin{tabular}{|c|c|c|c|c|c|c|c|c|c|}
\hline \multicolumn{2}{|c|}{ ANOVA test } & \multirow[t]{2}{*}{$\begin{array}{l}\text { Adjusted } \\
\text { R square }\end{array}$} & \multirow[t]{2}{*}{ Variables } & \multicolumn{2}{|c|}{$\begin{array}{l}\text { Unstandardized } \\
\text { Coefficients }\end{array}$} & \multirow[t]{2}{*}{$\mathbf{t}$} & \multirow[t]{2}{*}{$\mathbf{p}$} & \multicolumn{2}{|c|}{$\begin{array}{c}95.0 \% \\
\text { Confidence } \\
\text { Interval for B }\end{array}$} \\
\hline $\mathbf{F}$ & p & & & B & SE & & & Lower & Upper \\
\hline \multirow{6}{*}{6.689} & \multirow{6}{*}{$<0.001 *$} & \multirow{6}{*}{0.354} & (Constant) & 241.1 & 61.7 & 3.906 & $<0.001 *$ & 116.9 & 365.2 \\
\hline & & & $\begin{array}{l}\text { Manner of } \\
\text { poisoning } \\
\text { (suicidal) }\end{array}$ & -9.0 & 3.5 & $\begin{array}{c}- \\
2.550\end{array}$ & $0.014^{*}$ & -16.0 & -1.9 \\
\hline & & & GCS & -3.3 & 0.8 & $\begin{array}{c}- \\
4.300 \\
\end{array}$ & $<0.001 *$ & -4.9 & -0.5 \\
\hline & & & $\begin{array}{c}\mathrm{O}_{2} \\
\text { saturation }\end{array}$ & -1.7 & 0.6 & $\begin{array}{c}- \\
2.845\end{array}$ & $0.007 *$ & -3.0 & -0.5 \\
\hline & & & $\mathrm{PCO}_{2}$ & -0.6 & 0.2 & $\begin{array}{c}- \\
1.680\end{array}$ & 0.100 & -1.2 & 0.1 \\
\hline & & & $\mathrm{HCO}_{3}$ & 1.1 & 0.6 & 1.787 & 0.080 & -0.1 & 2.4 \\
\hline
\end{tabular}

$R$ square: square of residuals; SE: standard error.

\section{Discussion}

Antipsychotic poisoning is one of the top five substances most frequently involved in human poisoning as sedative hypnotics/antipsychotics poisoning represented $5.84 \%$ of cases in 2017. However, sedative hypnotic/antipsychotic poisoning increased most rapidly by $10.7 \%$ per 2017 (2088 cases/year) according to national poison data system (Gummin et al., 2017). Meanwhile, in Egypt, there is limited data about antipsychotic poisoning. Therefore, this study aimed to assess the pattern of toxicity in acute antipsychotic poisoned cases admitted to Tanta University Poison control Unit at emergency hospital throughout the period from $1^{\text {st }}$ of November 2016 to the end of October 2017.

In the present study, childhood and adolescence less than 20 year of age represented the majority of cases $(66.7 \%)$ which could be attributed to the rapid increase in the use and prescription of antipsychotic medication for children and adolescent in the last two decades for 
managing sleep disorders, anxiety and mood disorders so it became more available at home (Berling et al., 2016). Furthermore, suicidal attempt by psychiatric medications in adolescence were reported in previous study (Sheridan et al., 2017). This result was explained by factors like emotional disturbance, puberty changes, educational problems, family relationship and media influence (Bazrafshan et al., 2016). Also, the unsafe medications storage in addition to unsafe environment and insufficient supervision of children behavior can explain the increased children rate in the sample. Pediatric poisoning with antipsychotics is remarkably increasing in the last years and became a significant cause of morbidity (Meli et al., 2014, Dayasiri et al., 2017).

The higher female ratio $(65 \%)$ could be explained by the concept that females are socially and psychologically more vulnerable to drug poisoning than males in our culture (Boukatta et al., 2014, Shojaei et al., 2014, Georgiev et al., 2015, Borg et al., 2016, Toft et al., 2017). Most of our cases were unemployed (35\%) followed by students $(33.3 \%)$. The high rate of suicide among unemployed was reported to be due to their socioeconomic and psychological problems (Milner et al., 2014), while the poor family communication, parent's economic problems, educational problems and failure in love were reported to be the causes of suicide among students (Mohammadkhani et al., 2006).

Most of the studied cases with both suicidal and accidental poisoning were from urban areas (71.7\%), while $28.3 \%$ were from rural areas. This was also reported by some authors (Anthony and Kulkarni, 2012). Additionally, urban areas are at a higher risk of suicide due to more stressful life, family conflicts, job competitions and more liability for psychiatric disorders (Qin, 2005). Singles were more in our sample (71.7\%) than married. The decrease in social integration and maturity of single than married could explain their suicidal vulnerability (Griffiths et al., 2008).

Most of cases were poisoned by atypical antipsychotics $(81.7 \%)$ which coincided with the results founded by the study of Berling and his colleagues (Berling et al., 2016). This reflects the increase in the use of atypical antipsychotics than typical ones due to less neurological side effects as extrapyramidal manifestations (Ucok and Gaebel, 2008). The worldwide increase of suicide may explain the increase of suicidal poisoning in our cases $(71.7 \%)$ which coincided with other studies (Georgiev et al., 2015, Borg et al., 2016). Most of cases admitted to the hospital within 5 hours from ingestion (75\%) which could be attributed to the location of Tanta Poison Control Unit in the center of Delta with easy availability of transportation for it.

The clinical profile of antipsychotic poisoning in our cases demonstrated that about half of the studied cases had mild general symptoms like tachycardia $(46.67 \%)$, tachypnea (46.67\%) and miosis (56.7\%) while, small number were presented with serious manifestations like GCS less than $8(8.3 \%)$ and dystonia $(6.7 \%)$. This was in agreement with the previous reports of lower morbidity and lower lethal effect of antipsychotic poisoning in most of cases specially the atypical ones (Capel et al., 2000, Rasimas and Liebelt, 2012, Meli et al., 2014). Most of our cases didn't consume big doses and most of those who poisoned themselves intended only to seek attention not to kill themselves or ingested the drug accidentally.

CNS depression manifestations in the studied cases were related to acute intoxication with clozapine $(35 \%)$, it is known that tachycardia and CNS depression are common manifestations of its toxicity (Pickford, 2000, Kramer et al., 2010). This could be explained by the fact the that clozapine has a wide profile of receptor binding affinity (Sackey et al., 2017). Blood pressure changes were not common in our cases which were similar to previous studies (Tan et al., 2009, Gugger, 2011, Mucci et al., 2016, Ramnarine, 2017).

Tachypnea was observed in $46.67 \%$ of cases and no cases had bradypnea which could be attributed to stress and anxiety. Moreover, the absence of bradypnea could be explained in most of our cases by the absence of marked CNS depression. Studies showed that significant respiratory depression is not common with antipsychotic poisoning (Rasimas and Liebelt, 2012). Slurred speech was observed in $41.7 \%$ of the studied cases which agreed with the study of Kramer and his colleagues (Kramer et al., 2010) who reported dysarthria in $15.1 \%$ of cases intoxicated with clozapine.

The present study showed that pupil was constricted in more than half of cases $(56.7 \%)$, dilated in $3.3 \%$ and normal in $40 \%$ of cases. Pupil size changes were recorded by some previous researches (Pickford, 2000, Meli et al., 2014). Miosis was explained by the $\alpha_{1}$ adrenergic receptor blocking effect of antipsychotics while mydriasis was explained by the anticholinergic effect of these drugs (Stahl, 2013).

Dystonia was found in $6.7 \%$ of the studied cases who were intoxicated by chlorpromazine, haloperidol and risperidone. The low incidence of extrapyramidal manifestations in our study could be due to most of our cases were intoxicated by atypical antipsychotics $(81.7 \%)$ which are known to have a lower incidence of extrapyramidal manifestations than typical antipsychotics because of their lower dopamine receptor binding affinity (Divac et al., 2014). Poison severity score (PSS) revealed that most of cases showed mild severity (51.7\%), 33.7\% were moderate, $5 \%$ were severe and $10 \%$ had non grade poison severity score. No fatalities were recorded in our cases. This was similar to previous studies (Rasimas and Liebelt, 2012, Meli et al., 2014).

This study revealed ECG changes as tachycardia (50\%), QTc interval prolongation (43\%) which was reported to be the most common ECG changes in antipsychotic poisoning (Tan et al., 2009). The heart rhythm was regular with normal QRS morphology. Previous studies showed low risk of ventricular arrhythmia and cardiac arrest (Liperoti et al., 2005). T wave flattening and inversion was detected in $10 \%$ of cases which agreed with previous researches (Marano et 
al., 2011). Also, the majority of cases had prolonged QT interval and were poisoned by atypical antipsychotics (78\%) while $22 \%$ were poisoned with typical agents. On the other hand, Chohan and his colleagues stated that atypical antipsychotics were less commonly to prolong QTc interval than typical ones (Chohan et al., 2015). This difference could be attributed to over representation of atypical $(81.7 \%)$ than typical antipsychotics $(18.3 \%)$ in our sample. In this study, no cases presented with torsade de points which coincided with previous studies (Wenzel-Seifert et al., 2011).

Most of cases in this study had normal arterial blood gas $(66.7 \%)$ followed by respiratory alkalosis $(26.7 \%)$ then respiratory acidosis and mixed disorder were equally represented (3.3\% for each). This coincided with the results reported by Capel and his colleagues (Capel et al., 2000). Hypokalemia was found in $15 \%$ of our cases. Malik et al. reported hypokalemia with risperidone and quetiapine toxicity (Malik et al., 2005). Antipsychotics block potassium efflux channel and inhibit shifting of potassium from intracellular to extracellular space (Pal et al., 2015). Furthermore, Hyperglycemia was detected in $15 \%$ of our cases which could be attributed to the decrease in insulin sensitivity due to $5-\mathrm{HT}_{2 \mathrm{~A}}$ receptor antagonism by antipsychotics (Müller et al., 2009, Yam et al., 2013).

One case of acute clozapine toxicity $(1250 \mathrm{mg})$ showed high level of AST (51 U/L) and ALT (73 U/L). Other studies (Erdogan et al., 2004, Chou et al., 2014) reported also the elevation of liver enzymes with clozapine intake but this effect is usually asymptomatic and usually transient phenomenon. Leukocytosis was detected in $20 \%$ of cases while other cases had normal WBCs count. 50\% of cases who had leukocytosis were intoxicated by clozapine and the mechanism is still unknown but one possibility is that clozapine may induce the release of some cytokines as TNF, IL-2, IL-6, and GCSF (Fehsel et al., 2005). Another explanation of leukocytosis could be attributed to presence of infection such as pneumonia which developed in 2 cases in our study. Also, the results showed no abnormality in sodium, magnesium level and kidney function tests which coincided with the results reported by other authors (Capel et al., 2000).

The present study revealed that the median duration of hospital stay was 13 hours which is close to the results demonstrated by Berling and his colleagues (Berling et al., 2016). Most of the studied sample had just mild toxicity $(51.7 \%)$ with $53.3 \%$ of cases were discharged after complete recovery. Cases with GCS $<12$ stayed in the hospital for longer duration than other cases. This coincided with other studies (Abe et al., 2008). Regression analysis was done to find out risk factors that could predict hospital stay showed that decreased GCS, $\mathrm{PCO}_{2}$, and $\mathrm{O}_{2}$ saturation were associated with increased hospital stay in our studied cases. Abe and his colleagues also performed multiple regression analysis for the same purpose and they stated that cases stayed in the hospital longer were presented with tachycardia, lower blood pressure, altered consciousness and elevated white blood cells count (Abe et al., 2008). This difference in risk factors from our study could be explained by the fact that they studied all psychotropic drugs not only antipsychotics.

\section{Conclusion}

Acute antipsychotic poisoning is more in age group less than 30 years particularly females with mild to moderate severity of poisoning. Neurological and cardiovascular manifestations were the predominant manifestations. Sinus tachycardia and prolonged QTc were the most common electrocardiographic changes in antipsychotic poisoning. Most of cases were discharged after complete recovery which could reflect the good prognosis of antipsychotic poisoning. The decrease in GCS, PCO2, and $\mathrm{O} 2$ saturation were associated with increased hospital stay duration. These results should be considered in the view of inevitable limitation of our results due to the short duration of the study, the convenience nature of the sample and the restriction on one centre. So, larger sample from multiple centers with multi-staging randomization is recommended.

\section{Recommendations}

Cases with susceptibility of acute antipsychotic overdose should be referred to poison control unit as soon as possible as this will minimize the complications and improve the outcome. On the other hand, awareness campaigns for families about poison prevention strategies should be done regularly. These include; antipsychotic drugs should be away from the reach of children to prevent accidental poisoning. Also, mentally ill patients who treated with antipsychotics should have proper supervision to avoid overdose.

\section{References}

Abe, t., Tokuda, y., Stein, g. h.,.et al. 2008. risk factors associated with prolonged hospital stay in admitted patients with psychotropic drug overdose. open critical care medicine journal, 1, 12-16.

Anthony, L. \& Kulkarni, C. 2012. Patterns of poisoning and drug overdosage and their outcome among in-patients admitted to the emergency medicine department of a tertiary care hospital. Indian journal of critical care medicine, 16, 130.

Bazrafshan, M.-R., Sharif, F., Molazem, Z.,.et al. 2016. Exploring the risk factors contributing to suicide attempt among adolescents: A qualitative study. Iranian Journal of nursing and midwifery research, 21, 93-99.

Berling, I., Buckley, N. A. \& Isbister, G. K. 2016. The antipsychotic story: changes in prescriptions and overdose without better safety. $\mathrm{Br} \quad J$ Clin Pharmacol, 82, 249-254.

Borg, L., Julkunen, A., Rorbaek Madsen, K.,.et al. 2016. Antidepressant or antipsychotic overdose in the intensive care unit - Identification of patients at risk. Basic clinical pharmacology toxicology, 119, 110-114. 
Boukatta, B., El Bouazzaoui, G. R., Houari, N.,.et al. 2014. An epidemiological study of adult acute poisoning in Fez: Morocco. Journal of toxicology. Clinical toxicology, 4, 219.

Capel, M. M., Colbridge, M. G. \& Henry, J. A. 2000. Overdose profiles of new antipsychotic agents. Int J Neuropsychopharmacol, 3, 51-54.

Chohan, P. S., Mittal, R. \& Javed, A. 2015. Antipsychotic medication and QT prolongation. Pakistan journal of medical sciences, 31, 1269.

Chou, A. I. W., Lu, M.-L. \& SHEN, W. W. 2014. Hepatotoxicity induced by clozapine: a case report and review of literature. Neuropsychiatric disease and treatment, 10, 1585.

Dayasiri, M., Jayamanne, S. F. \& Jayasinghe, C. Y. 2017. Risk factors for acute unintentional poisoning among children aged 1-5 years in the rural community of Sri Lanka. International journal of pediatrics, 2017, 1-9.

Desilva, P., Fenton, M. \& Rathbone, J. 2006. Zotepine for schizophrenia. Cochrane Database Syst Rev, Cd001948.

Divac, N., Prostran, M., Jakovcevski, I.,.et al. 2014. Second-generation antipsychotics and extrapyramidal adverse effects. BioMed research international, 2014, 6.

Erdogan, A., Kocabasoglu, N., Yalug, I.,. et al. 2004. Management of marked liver enzyme increase during clozapine treatment: a case report and review of the literature. The International journal of psychiatry in medicine, 34, 83-89.

Fehsel, K., Loeffler, S., Krieger, K.,.et al. 2005. Clozapine induces oxidative stress and proapoptotic gene expression in neutrophils of schizophrenic patients. Journal of clinical psychopharmacology, 25, 419-426.

Georgiev, K., Georgieva, M., Marinov, P., et al. 2015. Acute poisonings with neuroleptics in clinic of toxicology of military medical academy Varna/Bulgaria registered for 20 year period. Scripta scientifica medica, 47, 70-72.

Griffiths, C., Ladva, G., Brock, A.,.et al. 2008. Trends in suicide by marital status in England and Wales, 1982-2005. Health statistics quarterly, 8.

Gugger, J. J. 2011. Antipsychotic pharmacotherapy and orthostatic hypotension. CNS drugs, 25, 659671.

Gummin, D. , Mowry, J. B., Spyker, D. A. and et al., 2017. 2016 Annual report of the American Association of Poison Control Centers' National Poison Data System (NPDS): 34th Annual Report. Clinical toxicology, 55, 1072-1254.

Isbister, G. K., Friberg, L. E., Hackett, L. P.,.et al. Pharmacokinetics of quetiapine in overdose and the effect of activated charcoal. Clinical pharmacology and therapeutics, 81, 821- 827.

Kim, J., Kim, M., Kim, Y. R.,.et al. 2015. High prevalence of psychotropics overdose among suicide attempters in Korea. Clin

Psychopharmacol Neurosci, 13, 302-307.

Kramer, I., Rauber-Luthy, C., Kupferschmidt, H.,.et al. 2010. Minimal dose for severe poisoning and influencing factors in acute human clozapine intoxication: a 13-year retrospective study. Clinical neuropharmacology, 33, 230-234.

Liperoti, R., Gambassi, G., Lapane, K. L.,.et al. 2005. Conventional and atypical antipsychotics and the risk of hospitalization for ventricular arrhythmias or cardiac arrest. Arch Intern Med, 165, 696-701.

Malik, A. R., Wolf, P. K. \& Ravasia, S. 2005. Hypokalemia from risperidone and quetiapine overdose. The Canadian journal of psychiatry, $50,76-76$

Marano, G., Traversi, G., Romagnoli, E.,.et al. 2011. Cardiologic side effects of psychotropic drugs. Journal of geriatric cardiology 8, 243-253.

Meli, M., Rauber-lüthy, C., Hoffmann-walbeck, P.,.et al. 2014. Atypical antipsychotic poisoning in young children: a multicentre analysis of poisons centres data. European journal of pediatrics, 173, 743-750.

Milner, A., Morrell, S. \& Lamontagne, A. D. 2014. Economically inactive, unemployed and employed suicides in Australia by age and sex over a 10-year period: what was the impact of the 2007 economic recession? International journal of epidemiolology, 43, 1500-1507.

Minns, A. B. \& Clark, R. F. 2012. Toxicology and overdose of atypical antipsychotics. J Emerg Med, 43, 906-913.

Mohammadkhani, P., Mohammadi, M., Delavar, A.,.et al. 2006. Predisposing and precipitating risk factors for suicide ideations and suicide attempts in young and adolescent girls. Medical journal of The Islamic Republic of Iran (MJIRI), 20, 123-129.

Mowry, J. B., Spyker, D. A., Brooks, D. E.,.et al. 2016. 2015 Annual report of the American Association of Poison Control Centers' National Poison Data System (NPDS): 33rd Annual Report. Clinical Toxicology, 54, 924-1109.

Mucci, N., Giorgi, G., De Pasquale Ceratti, S.,.et al. 2016. Anxiety, stress-related factors, and blood pressure in young adults. Frontiers in psychology, 7, 1682.

Müller, C., Reuter, H. \& Dohmen, C. 2009. Intoxication after extreme oral overdose of quetiapine to attempt suicide: pharmacological concerns of side effects. Case reports in medicine, 2009.

Pal, A., Samanta, S., Samanta, S. \& Wig, J. 2015. Sustained ventricular tachycardia after electroconvulsive therapy: Can it be prevented? Indian journal of psychological medicine, 37, 247.

Persson, H. E., Sjoberg, G. K., Haines, J. A.,.et al. 1998. Poisoning severity score. Grading of acute 
poisoning. Journal of toxicology. clinical toxicology, 36, 205-213.

Pickford, M. 2000. Antipsychotic drug overdose. Emergency nurse, 7, 17-22.

Qin, P. 2005. Suicide risk in relation to level of urbanicity - a population-based linkage study. International journal of epidemiology, 34, 846852.

Ramnarine, M. 2017. Anticholinergic Toxicity [Online]. medescape.

Available: https://emedicine.medscape.com/article/812644overview [Accessed].

Rasimas, J. J. \& Liebelt, E. L. 2012. Adverse effects and toxicity of the atypical antipsychotics: What is Important for the pediatric emergency medicine practitioner. Clinical pediatric emergency medicine, 13, 300-310.

Sackey, B., Miller, L. J. \& Davis, M. C. 2017. Possible clozapine overdose-associated thromboembolic event. Journal of clinical psychopharmacology, 37, 364-366.

Sheridan, D. C., Hendrickson, R. G., Lin, A. L.,.et al. 2017. Adolescent suicidal ingestion: national trends over a decade. Journal of adolescent health, 60, 191-195.
Shojaei, A., Moradi, S., Alaeddini, F.,.et al. 2014. Association between suicide method, and gender, age, and education level in Iran over 2006-2010. Asia-Pacific psychiatry, 6, 18-22.

Stahl, S. M. 2013. Antipsychotic agents. In: STAHL, S. M. (ed.) Stahl's essential psychopharmacology. $4^{\text {th }}$ ed. New York: Cambridge University press.

Tan, H. H., Hoppe, J. \& Heard, K. 2009. A systematic review of cardiovascular effects following atypical antipsychotic medication overdose. The American journal of emergency medicine, 27, 607-616.

Toft, S., Horwitz, H. \& Dalhoff, K. P. 2017. Long-term mortality after poisoning with antipsychotics. Clin Toxicol (Phila), 55, 267-274.

Ucok, A. L. P. \& Gaebel, W. 2008. Side effects of atypical antipsychotics: a brief overview. World Psychiatry, 7, 58-62.

Wenzel-Seifert, K., Wittmann, M. \& Haen, E. 2011. QTc prolongation by psychotropic drugs and the risk of Torsade de Pointes. Deutsches Ärzteblatt International, 108, 687-693.

Yam, M. F.-C., Kiew, C.-F. \& Chong, C.-P. 2013. Hyperglycemia and late onset seizures associated with quetiapine overdose. Tzu Chi medical journal, 25, 119-121. 


\section{الملخص العربيى}

\section{تقييم حالات التسمم الحاد بمضادات الذهان بوحدة علاج التسمم بجامعة طنطا}

\section{مروة أحمد مبارك و إيناس إبراهيم المداح و دعاء محمد الغرباوى و مجدى محمد عشماوى'}

يعد التسمم بمضادات الذهان واحد من أكثر خمسة مواد يتسمم بهم الإنسان حيث يمثل التسمم بالمنومات / مضادات الذهان

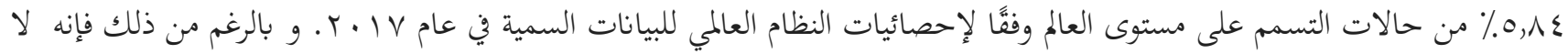
يوجد بمصر العديد من الدراسات الخاصة بالتسمم بهذه الأدوية.

المدف من الدراسة: كان المدف من إجراء هذا البحث تقييم نمط التسمم وتطور حالات التسمم الحاد بمضاد الذهان والذين تم استقبالهم وعلاجهم بوحدة علاج التسمم في مستشفى الطوارئ بجامعة طنطا. طرق البحث: أجريت هذه الدراسة على الحالات التي تم استقبالها في وحدة علاج التسمم بجامعة طنطا واشتكت من تناول جرعات

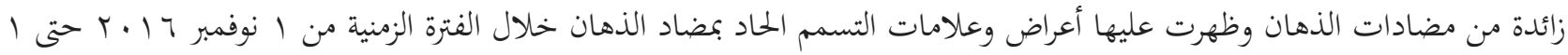
نوفمبر VI ا • و وتم عمل الفحص الطبي الشامل للمرضى والفحوصات المعملية و رسم القلب وتم علاجهم و تتبع تطور هذه الحالات و معرفة مصيرها.

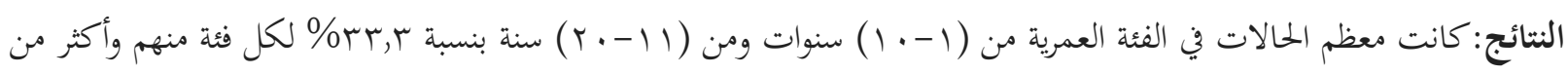

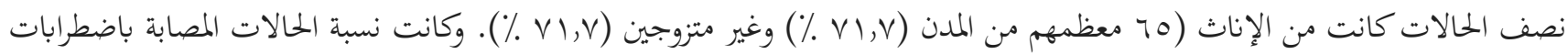

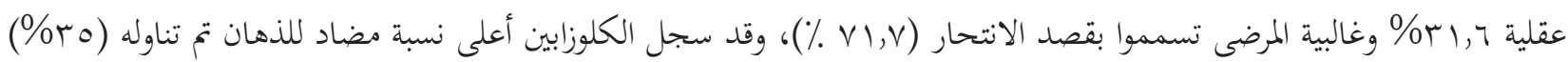

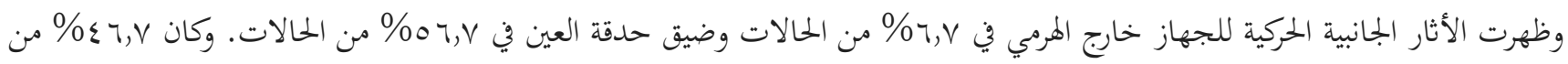

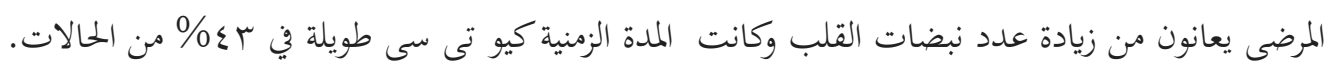

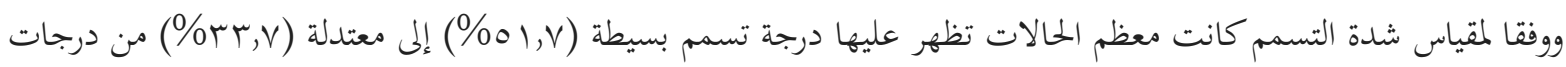
التسمم، وتم دخول حالة واحدة أثناء الدراسة إلى العناية المركزة. وأظهرت نتائج اختبار تحليل الانحدار المتعدد أن الخفاض كل من درجة الوعي الوعي

طبقا لمقياس الغيبوبة جلاسكو و ثانى أكسيد الكربون في البلازما و نسبة تشبع الهيموجلوبين بالأكسجين كان مرتبطا بزيادة مدة الإقامة في المستشفى لحالات التسمم الحاد بمضاد الذهان.

الاستنتاج:إن معظم حالات التسمم الحاد بمضادات الذهان تكون بسيطة إلى معتدلة السمية طبقا لمقياس شدة التسمم، وتعد أعراض الجهاز العصبي المركزى والقلب و الأوعية الدموية هي الأكثر شيوعا في هذه الحالات، و تعد زيادة سرعة نبضات القلب و المدة الزمنية كيو تى سى الأكثر شيوعا في رسم القلب، و غالبا ما يكون مصير حالات التسمم هذذه الأدوية جيد.

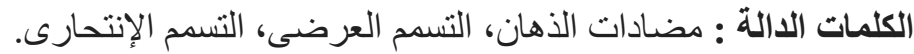

